\title{
Mediterranean Mountains in the Mythological Paintings of European Art
}

\author{
By Sibel Almelek İsman*
}

\begin{abstract}
European painters have depicted Greek and Roman mythologies for centuries. Most of these narratives take place at certain locations in the Eastern Mediterranean region. This research will focus on the mountains that are mentioned in the mythology and give examples of the paintings that show related tales. These pictures are selected from a wide span of time from the Baroque period until the 19th century. Mount Olympos was the home of twelve Olympian Gods. Apollo and the Muses lived on Mount Parnassus. Two springs sacred to the Muses, were located on the Mount Helicon. Paris was living as a shepherd on Mount Ida in Anatolia. Ganymede was abducted by Zeus from Mount Ida. Anchises was tending sheep on Mount Ida when he was seduced by Aphrodite. Zeus was raised on Mount Ida in Crete. Selene' s lover Endymion slept peacefully in a cave of Mount Latmos.
\end{abstract}

\section{Introduction}

Greek and Roman mythologies have been an important source of inspiration for European artists for centuries. The stories of gods, goddesses, heroes and heroines were picturised on canvases as well as on walls. Most of these narratives take place in the Eastern Mediterranean region. Actual geographical details such as the names of the mountains, hills, rivers, springs and islands can be seen in the mythology. This research will focus on the mountains that are mentioned in the mythology and give examples of the paintings that show related tales. These pictures are selected from a wide span of time from the Baroque period until the $19^{\text {th }}$ century. At the present time, some of these mountains - Olympos, Parnassus, Helicon, and Ida - are in Grece and others - Ida (Kazdağları) and Latmus (Beşparmak) - are in Turkey.

\section{Mount Olympus}

Mount Olympus is the highest mountain in the Greek peninsula, dominating the Aegean to the east and, to the north and south, The Macedonian and Thessalian plains. Considered to be the throne of Zeus and home of the gods, it held an important place in religion, mythology and literature. ${ }^{1}$

In Greek and Roman mythology the twelve gods of Olympus ruled the world after the defeat of the Titans. Most were believed to dwell on Mount

\footnotetext{
*Assistant Professor, Buca Faculty of Education, Dokuz Eylül University, Turkey.

1. Simon Price and Emily Kearns, Oxford Dictionary of Classical Mythology \& Religion (Oxford: Oxford University Press, 2004), 388.
} 
Olympus, whose peaks were shrouded in cloud and therefore hidden from mortal sight. Olympus was presided over by Zeus and his wife Hera. With them lived Zeus' brother Poseidon and their sisters Demeter and Hestia. With six of Zeus' children, these comprised the twelve Olympian gods. ${ }^{2}$ Homer, mentions Mount Olympus several times in the Iliad. Mount Olympus is referred to as gleaming and great in the Iliad: ${ }^{3}$

The son of Cronos spoke, and bowed his dark brow in assent, and the ambrosial lock waved from the king's immortal head; and he made great Olympus quake. When the two had taken counsel together in this way, they parted; she leapt straightway into the deep sea from gleaming Olympus, and Zeus went to his own palace.

Italian Neoclassical artist Andrea Appiani (1754-1817) depicted the coronation of Zeus in his painting The Olympus (1806) (Image 1), which was the pendant of Parnassus, now lost, was intended to decorate a study in the Palazzo Reale in Milan, but it was never installed there. A transparent allegory of Napoleon's power, The Olympus displays the academic and courtly aspect of the personality of Appiani, the most famous exponent of the Neoclassical movement in Milan, and also Napoleon's court painter in Italy. ${ }^{4}$

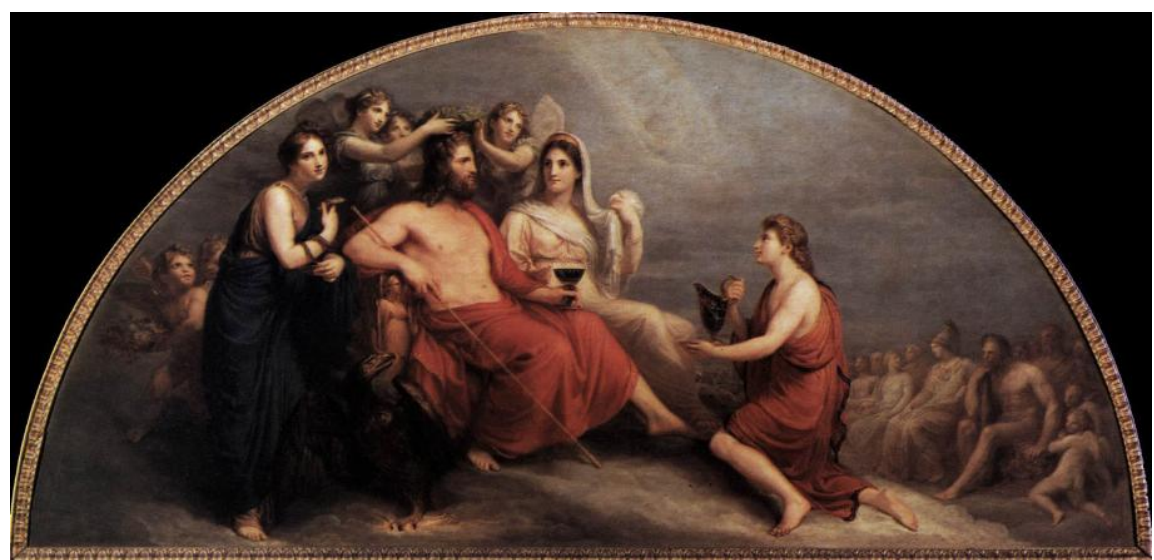

Image 1. Andrea Appiani, The Olympus, oil on canvas, $45 \times 136 \mathrm{~cm}$, Pinacoteca di Brera, Milan

2. Malcolm Day, 100 Characters from Classical Mythology (New York: Barron's Educational Series, 2007), 23.

3. Homer, The Iliad, translated from Greek by E. Earl of Derby (London: J. M. Derit \& Sons, 1910), Book I, 528-532. (Original date: 8th - 7th B.C.).

4. Silvana Margazalli (ed.), The Brera Gallery: The Official Guide, translated from Italian by D. Stanton (Milan: Touring Editore, 1998), 316. 


\section{Mount Parnassus}

Mount Parnassus, outlying spur of the Pindus range, runs south-east and into the Corinthian Gulf at Cape Opus. It was a sacred mountain, especially to the Dorians. ${ }^{5}$

French Baroque artist Simon Vouet (1590-1649) in his painting Parnassus (c. 1640) (Image 2), depicted Apollon playing his lyre among the nine muses in the woods of Mount Parnassus. The Muses were an daughters of the Titaness Mnemosyne and Zeus. They were the source of inspiration to artists, writers and musicians. Believed to be virgins living in the woods, sometimes near fountains, they were often depicted holding hands and dancing in a circle to symbolize the connection between the arts. ${ }^{6}$

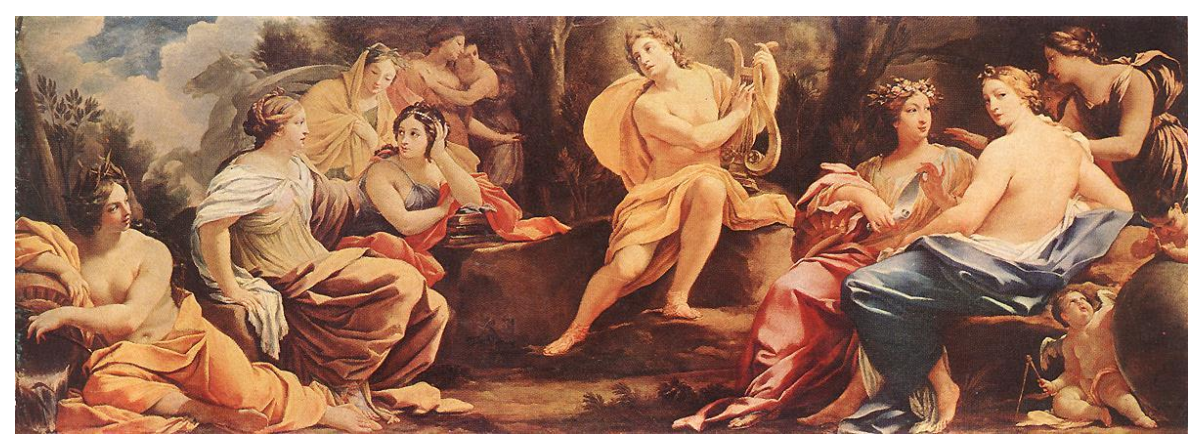

Image 2. Simon Vouet, Parnassus, c. 1640, oil on panel, $88 \times 222 \mathrm{~cm}$, Szèpmûvèszeti Múzeum, Budapest

\section{Mount Helicon}

Mount Helicon which is sacred to the Muses is in south-west Boeotia. Its most famous feature is the Valley of the Muses. Thespiae celebrated a festival of the muses. ${ }^{7}$

Flemish Baroque artist Joos de Momper (1564-1635), depicted Minerva, the Muses and Pegasus in his painting Helicon or Minerva's Visit to the Muses (Image 3). The Muses are playing their instruments in the company of Minerva in a pleasing and calm mountain scenery.

Ovid describes in the Metamorphoses how Minerva visited the Muses on Mount Helicon to listen to their songs and see the sacred spring, the

5. Simon Price and Emily Kearns, Oxford Dictionary of Classical Mythology \& Religion, 407.

6. Malcolm Day, 100 Characters from Classical Mythology, 66.

7. Simon Price and Emily Kearns, Oxford Dictionary of Classical Mythology \& Religion, 246. 
Hippocrene, which flowed from a rock after it had been struck by the hoof of the winged horse, Pegasus: ${ }^{8}$

Minerva supported her brother, born in the shower of gold throughout these trials. But now she wrapped herself in a hollow cloud and departed from Seriphos. Cythnos and Gyaros lay to her right; then finding the shortest crossing over the sea, she headed towards Thebes and the mountain of Helicon, home of the Muses. Here she landed and spoke to the sisters who govern the art: "A rumour has come to my ears of a fountain that started to gush when the earth was struck by the hoof of the winged horse sprung from Medusa. Hence my arrival. I wanted to see this amazing spring, as I witnessed the horses's birth from the blood of his Gorgon mother." Urania answered: "Whatever your reason for coming to visit us here in our home, kind goddess, we feel great pleasure. The story you heard is correct: the winged horse Pegasus stred our spring"; and she took Minerva down to the sacred mountain.

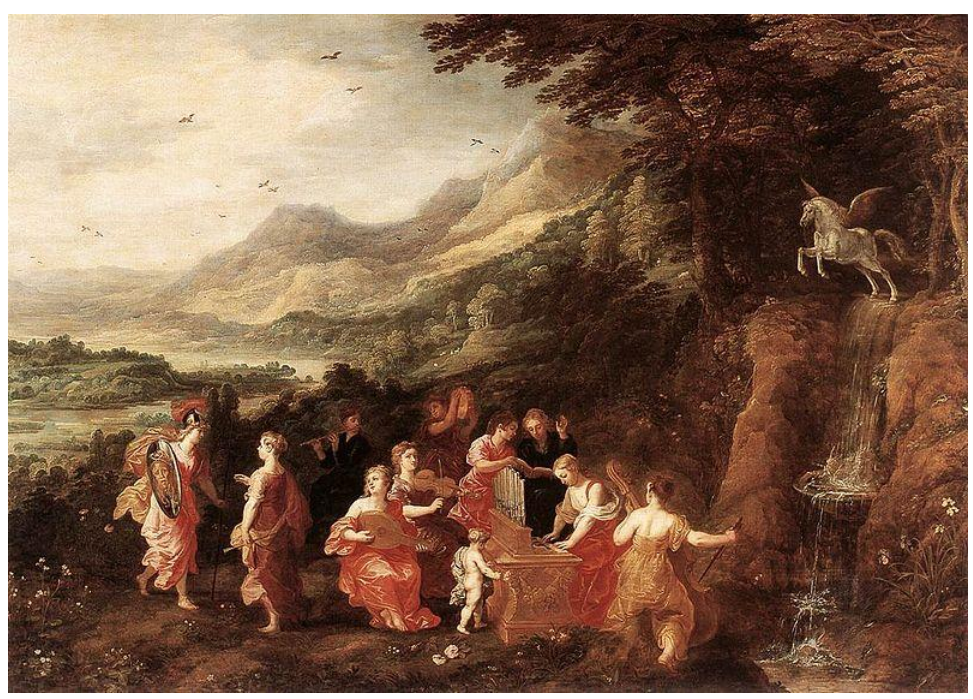

Image 3. Joos de Momper, Helicon or Minerva's Visit to the Muses, oil on panel, 140 x 199 cm, Koninklijk Museum voos Schone Kunsten, Antwerp

\section{Mount Ida (Crete)}

Cronus had swallowed five of his children to avert a prophecy that one of them would overthrow him and rule the world. His wife, Rhea, saved their sixth child, Zeus, by placing him to the nymphs and shepherds on Mount Ida

8. Ovid, Metamorphoses, translated from Latin by D. Raeburn (London: Penguin Books, 2004), Book 5, 250-262. (Original date: $1^{\text {st }}$ A.D.). 
in Crete, where he was nourished with milk from the she-goat Amalthea and fed with sweet honey. Apollodorus tells this story in his Library: ${ }^{9}$

Rhea went to crete while she was pregnant with Zeus, and brought him to birth in a cave on Mount Dicte. She gave him to the Curetes and to the nymphs Adrasteia and Ida, daughters of Melisseus to rear. So the nymps fed the child on the milk of Amaltheia while the curetes, fully armed, guarded the baby in the cave.

Dutch Baroque painter Nicolaes Berchem (1620-1683), depicted the infancy of Zeus in his painting The Infant Zeus with the Nymphs on Mount Ida dated 1650 (Image 4). Berchem used a sunny mountainous landscape as a setting for the early life of Zeus. The leader of the gods can be seen among the nymphs and nurtured by the goat.

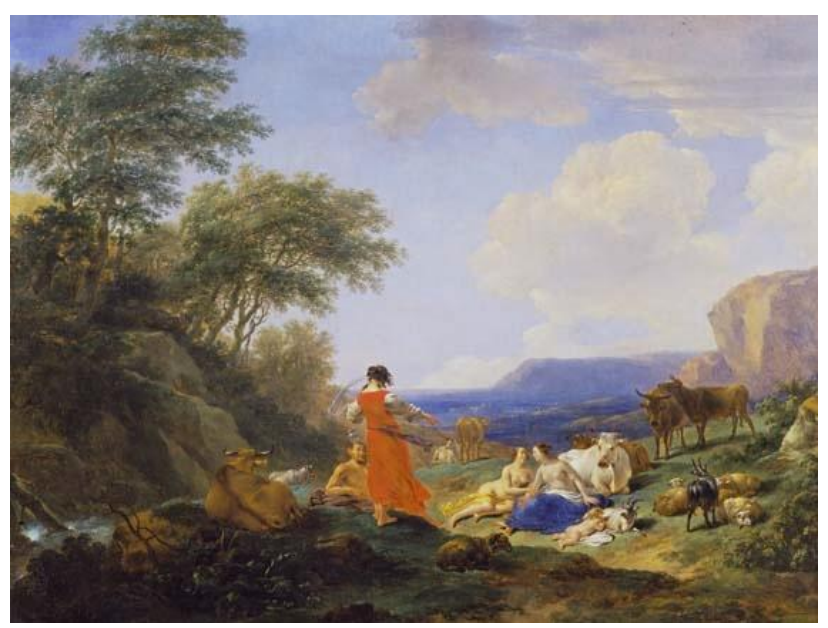

Image 4. Nicolaes Berchem, The Infant Zeus with the Nymphs on Mount Ida, 1650, oil on canvas, $63.3 \times 84.2 \mathrm{~cm}$, The Wallace Collection, London

\section{Mount Ida (Kazdağları)}

There are several mythological stories which take place on Mount Ida (Kazdağları) in Anatolia. The Judgement of Paris, the passionate union of Zeus and Hera, the meeting of Aphrodite and Anchises and the abduction of Ganymede are important episodes related to this mountain.

The Judgment of Paris (the son of a Trojan king, Priam) is the one of the most popular mythological themes in art. The scene on Mount Ida depicts the story of Paris' award of the golden apple to Aphrodite in a contest of beauty between her, Hera, and Athena.

9. Apollodorus, The Library, translated from Greek by J.G. Frazer (London: William Heinemann, 1921), Book I, 1.6-7. (Original date: 3rd century B.C.). 
Eris, the goddess of strife and discord, threw a golden apple marked "to the fairest" amidst the gods and Zeus selected Paris, a Trojan shepherd, to award it. Apollodorus tells the story in Library: ${ }^{10}$

Eris threw an apple in front of Hera, Athena and Aphrodite as a prize for the most beautiful, and Zeus instructed Hermes to take them to Alexander on Mount Ida, to be judged by him for their beauty. They promised to give Alexander gifts; Hera promised him universal dominion if she were preferred above all other women, while Athena offered victory in was, and Aphrodite the hand of Helen. He decided in favour of Aphrodite, and sailed to Sparta whit ships built by Phereclos.

French Baroque artist Claude Lorrain (1604-1682), in The Judgment of Paris (1645) (Image 5), gathered the four figures of the story to the left hand corner of the picture. The three goddesses can be recognised by the atributes attached to them. Lorrain depicted Hera attended by her peacock, Aphrodite accompanied by her son Eros and Athena with a spear at her side.

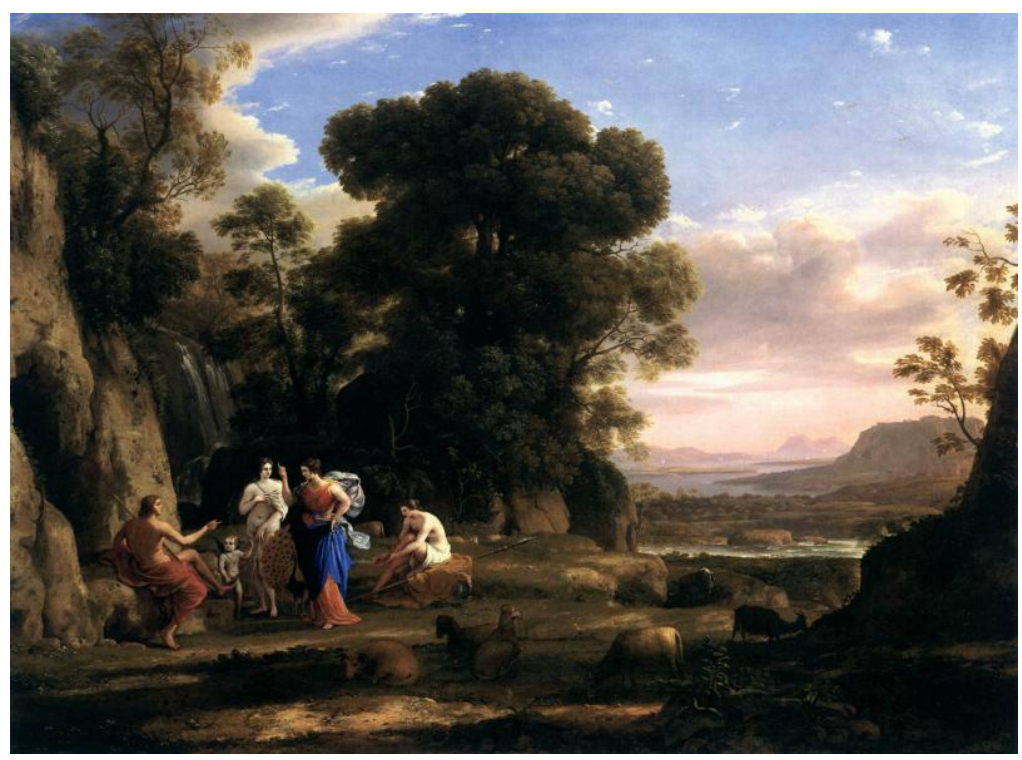

Image 5. Claude Lorrain, The Judgment of Paris, 1645, oil on canvas, $112.3 \times$ $149.5 \mathrm{~cm}$, National Gallery of Art, Washington

In an episode of Iliad, ${ }^{11}$ Hera makes an excuse to leave her divine husband Zeus. In her deception speech she declares that she wishes to go to Oceanus and Tethys. Instead Hera beautifies herself in preparation for seducing Zeus and obtains the help of Aphrodite. In the climax of the

10. Apollodorus, The Library, Book III, Epit. 3. 2.

11. Homer, The Iliad, Book XIV, 291-295. 
episode, Zeus and Hera make love hidden within a golden cloud on the summit of Mount Ida. By distracting Zeus, Hera makes it possible for the Greeks to regain the upper hand in the Trojan War.

Hera moved quickly on to Ida's peak, high Gargarus. Cloud-gatherer Zeus caught sight of her. As he looked, his wise heart became suffused with sexual desire, as strong as when they'd first made love together, lying on a couch without their parents' knowledge.

Irish Neoclassical painter James Barry (1741-1806) in Zeus and Hera on Mount Ida, (1790-99) (Image 6), depicted the divine couple on the summit of the Mount Ida, their faces and bodies approaching to each other with great passion among the clouds.

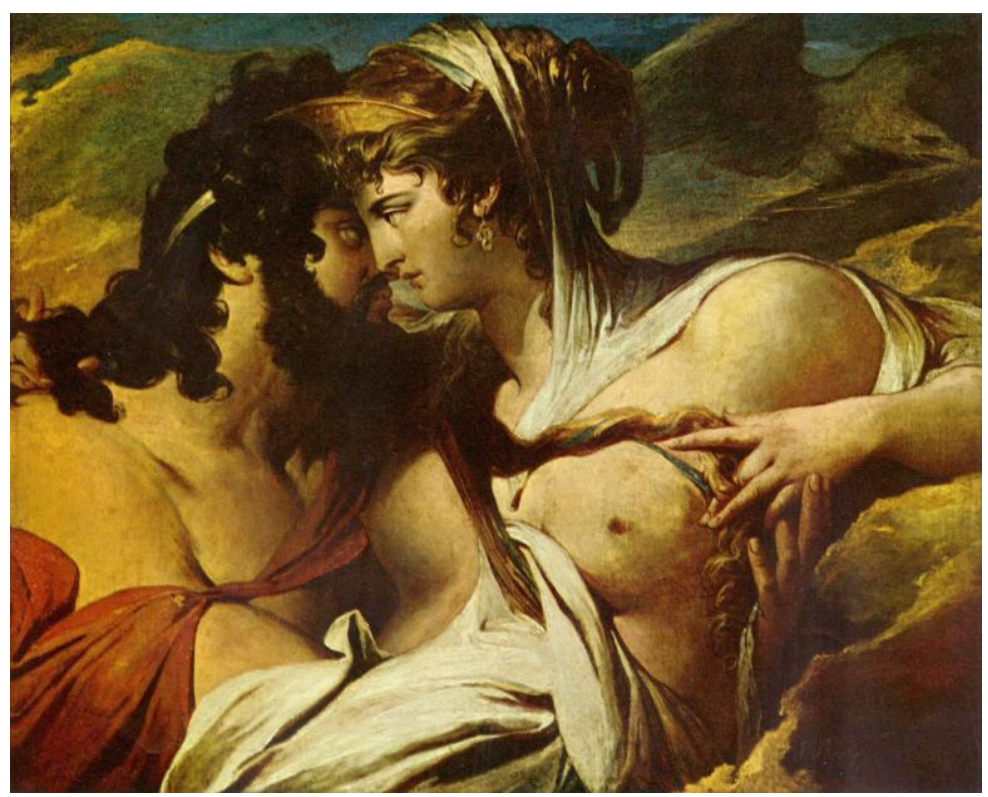

Image 6. James Barry, Zeus and Hera on Mount Ida, Sheffield City Museum, Sheffield

Ganymede, a Trojan prince, according to Homer, because of his great beauty, was snatched up by the gods to be Zeus' cup bearer on Olympus. In literature there are several versions of the abduction itself. In early myth Ganymede was carried of by a whirlwind, but later he was snatched up by an eagle, either a servant of Zeus bringing the boy to his master, or Zeus himself in disguise. ${ }^{12}$ Virgil describes the scene in Aeneid: ${ }^{13}$

12. Jennifer March, Dictionary of Classical Mythology (Oxford: Oxbow Books, 1998), 201-202.

13. Virgil, The Aeneid, translated by J. Dryden. The Internet Classics Archive http://goo.gl/qtN1xm, May 8, 2015, Book 5, 254-7. (Original date: 1st B.C.) 
Down from Ida swooped the bird who is armour-bearer to Zeus and snatched the boy up in its hooked talons, high into the heavens, while the old man who had cared for him streched their hands vainly towards the stars, ant the dog barked their fury into the air.

Flemish Baroque artist Peter Paul Rubens (1577-1640) in The Abduction of Ganymede, 1611-12 (Image 7), depicted the beatiful young shepherd embraced by the eagle in the center of the picture. The gods of Olympos can be seen seated around a table on the clouds which reminds the spectator about the aftermath of the story, Ganymedes being the cupbearer on Mount Olympos.

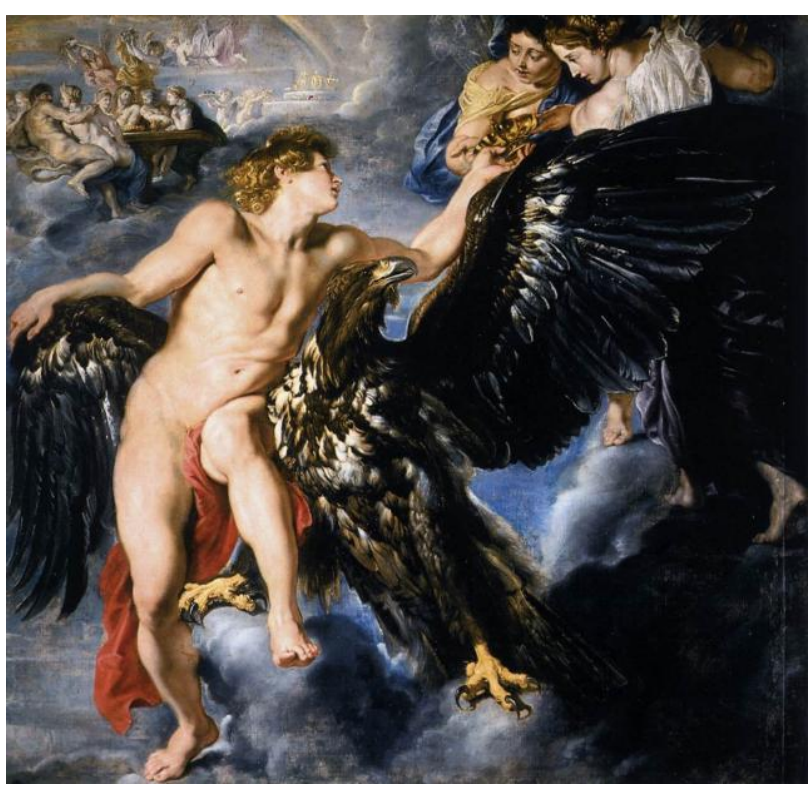

Image 7. Peter Paul Rubens, The Abduction of Ganymede, 1611-12, oil on canvas, 203 x 203 cm, Schwarzenberg Palace, Vienna

Anchises, son of Capys and Themis, was so beautiful that Aphrodite came down from heaven on Mount Ida to enjoy his company. ${ }^{14}$ This love story is told in one of the Homeric Hymns: ${ }^{15}$

And so he made her hanker for Anchises.

Among the many springs of Ida's tall peaks

He herded cows in all his godlike beauty.

When humorous Aphrodite got her first look

She fell in love - her mind was gone completely.

14. Percival George Woodcock, Short Dictionary of Mythology (New York: Philosophical Library, 1953), 13.

15. Homer, Homeric Hymns, translated from Greek by S. Ruden (Indianapolis: Hackett Publishing Company, 2005), Hymn 5 to Aphrodite, 53-55. (Original date: 7th6th B.C.). 
English Romantic artist Benjamin Haydon (1786-1846), Aphrodite and Anchises, 1826 (Image 8) depicted the love goddess with her young lover playing his lyre in the nature.

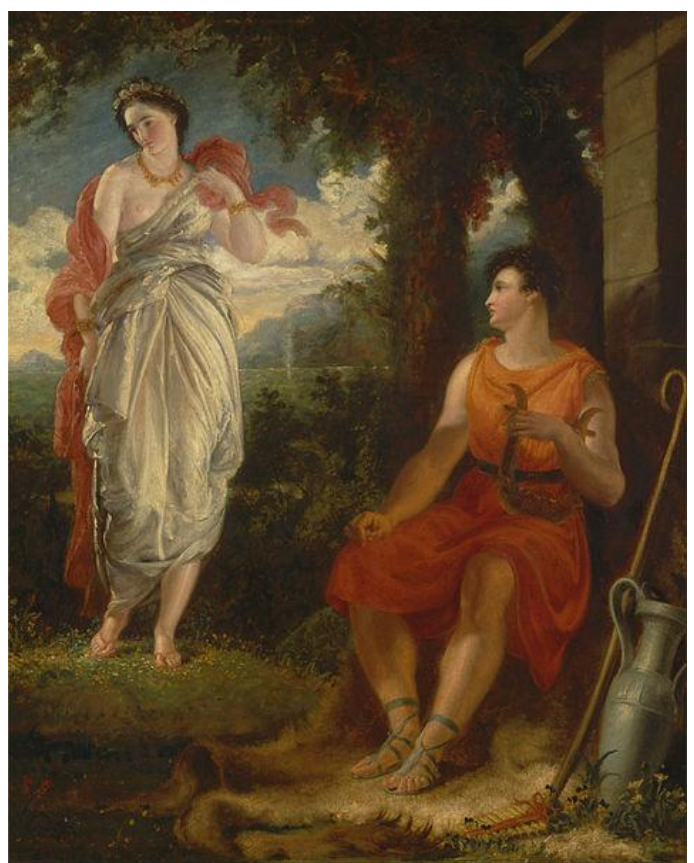

Image 8. Benjamin Haydon, Aphrodite and Anchises, 1826, oil on canvas, Yale Center for British Art, Connecticut

\section{Mount Latmus (Beşparmak)}

Moon goddess Selene fell in love with a handsome shepherd named Endymion, a son of Zeus and nymph Calyce. She was attracted to him when she saw him asleep in a cave on Mount Latmus in Ionia. She lay down beside him and gently kissed his eyes. They had fifty daughters, but Selene did not wish her mortal lover to die, so she put him to sleep forever. ${ }^{16}$ Apollonius Rhodius tells this love story in Argonautica: ${ }^{17}$

And the Titanian goddess, the moon, rising from a far land, beheld her as she fled distraught, and fiercely exulted over her, and thus spake to her own heart: "Not I alone then stray to the Latmian cave, nor do I alone burn with love for fair Endymion; often times with thoughts of love have I been driven away by thy crafty spells, in order that in the darkness of night tho mightest work thy sorcery at ease, even the deeds dear to thee."

16. Malcolm Day, 100 Characters from Classical Mythology, 60.

17. Apollonius Rhodius, Argonautica, translated from Latin by R. C. Seaton (London: William Heinemann, 1912), Book IV, 55-59. (Original date: 3rd B.C.). 
Dutch Baroque painter Gérard de Lairesse (1640-1711) depicted the moon goddess accompanied by Eros whose torch symbolizes burning love quietly creeping down to the shepherd Endymion in his painting Endymion and Selene (1680) (Image 9).

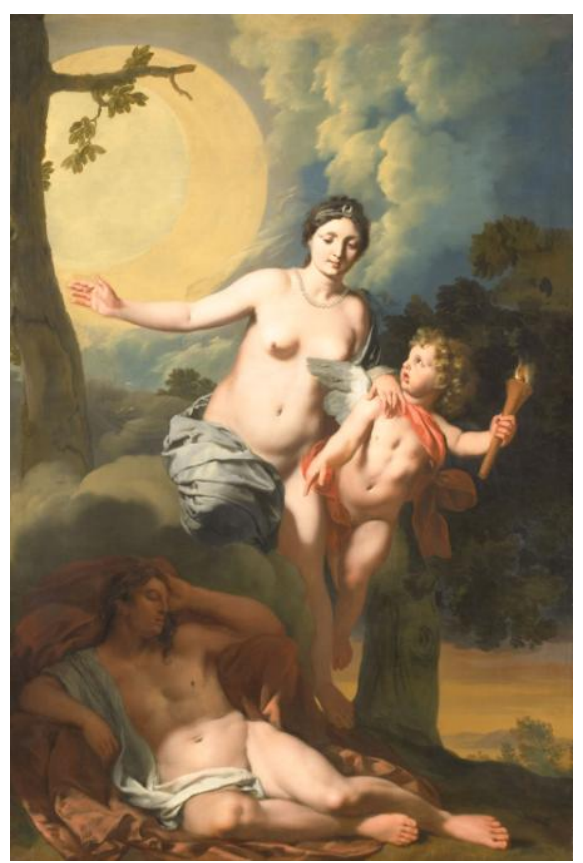

Image 9. Gérard de Lairesse, Selene and Endymion, 1680, oil on canvas, 118,5 x 177 cm, Rijksmuseum, Amsterdam

\section{Conclusion}

There are other mountains both in Greece and Turkey that can be named in relation to mythological stories. The Greek hero Heracles died on Mount Oeta in Greece. When Heracles wore the robe Deianira anointed with the blood of Centaur Nessus, a fearful pain seized him, as though he was in a burning fire. He ordered those around him to build a great pyre on Mount Oeta and carry him to it. When at last he reached it he knew that now he could die and he was glad. ${ }^{18}$

Hermes was born in a sacred cave on Mount Cyllene in Greece. The Messenger of gods was reffered as Cyllenian in Homeric Hymns: ${ }^{19}$

I sing of Cyllenian Hermes, the Slayer of Argus, lord of Cyllene and Arcadia rich in flocks, luck-bringing messenger of the deathless gods. He

18. Edith Hamilton, Mythology: Timeless Tales of Gods and Heroes (New York: Mentor, 1969), 171.

19. Homer, Homeric Hymns, Hymn to Hermes, 1-4. 
was born of Maia, the daughter of Atlas, when she had made love with Zeus, a shy goddess she.

Mount Sipylus in Turkey recalls the story of a sad mother. Niobe was the mother of six daughters and six sons. Being proud of the number of her children, she deemed herself superior to Leto, who had given birth to only two children. Leto's children Apollo and Artemis who were indignant at such presumption, killed all of Niobe's children with their arrows. Niobe who had gone to Mount Sipylus, was turned into stone. Homer tells the transformation of Niobe in Iliad: ${ }^{20}$

And now somewhere amid the rocks, on the lonely mountains, on Sipylus, where, men say, are the couching places of goddesses, even of the nymphs that range swiftly in the dance about Achelous, there albeit a stone, she broodeth over her woes sent by the gods.

As stated at the beginning, there are many actual names of Mediterranean geography in the Greek and Roman mythologies. Some of these mountains, rivers and islands are depicted by European artists. On the other hand, some of them are not encountered in artworks. For example, neither the birthplace of Hermes nor the deathplace of Niobe are picturised by European painters. It is important to know the whereabouts of the mythological characters to understand and visualise their stories better. For that reason, examining European mythological paintings from a geographical viewpoint provides enriching information.

\section{Bibliography}

Apollodorus. The Library. Translated from Greek by J.G. Frazer, London: William Heinemann, 1921. (Original date: 3rd century B.C.).

Apollonius Rhodius. Argonautica. Translated from Latin by R.C. Seaton. London: William Heinemann, 1912. (Original date: 3rd B.C.).

Day, Malcolm. 100 Characters from Classical Mythology. New York: Barron's Educational Series, 2007.

Hamilton, Edith. Mythology: Timeless Tales of Gods and Heroes. New York: Mentor, 1969.

Homer. Homeric Hymns. Translated from Greek by S. Ruden. Indianapolis: Hackett Publishing Company2005. (Original date: 7th-6th B.C.).

20. Homer, The Iliad, Book XXIV, 602-613. 
Homer. The Iliad. Translated from Greek by E. Earl of Derby. London: J. M. Derit \& Sons, 1910. (Original date: 8th-7th B.C.).

March, Jennifer. Dictionary of Classical Mythology. Oxford: Oxbow Books, 1998.

Margazalli, Silvana (ed.). The Brera Gallery: The Official Guide. Translated from Italian by D. Stanton. Milan: Touring Editore, 1998.

Ovid. Metamorphoses. Translated from Latin by D. Raeburn. London: Penguin Books, 2004. (Original date: 1st A.D.)

Price, Simon and Kearns, Emily. Oxford Dictionary of Classical Mythology $\mathcal{E}$ Religion. Oxford: Oxford University Press, 2004.

Woodcock, Percival George. Short Dictionary of Mythology. New York: Philosophical Library, 1953.

Virgil, The Aeneid, Translated by J. Dryden. The Internet Classics Archive http://goo.gl/qtN1xm, May 8, 2015. (Original date: 1st B.C.) 